\title{
The Unintended Consequences of Democratic Reforms: Electronic Voting and Criminal Violence in Brazil
}

\author{
Camilo Nieto-Matiz* $\quad$ Natán Skigin ${ }^{\dagger}$
}

This version: February 22, 2020

\begin{abstract}
Traditional theories of democracy posit that political competition promotes peaceful societies. By settling disputes through elections, democratic regimes are assumed to provide institutional mechanisms through which to channel otherwise possible violent conflict. Yet there is little support to such a claim, partly because the relationship between violence and competitive elections is largely endogenous. Exploiting the staggered implementation of a political reform in Brazil that gradually introduced electronic voting to reduce election rigging, we provide strong evidence that democratizing reforms can significantly reduce local levels of conflict. Results from a regression discontinuity design indicate that violence diminished by half standard deviation in municipalities where the electorate size was barely above 40,500, the magnitude that dictated whether electronic vote was first adopted, as compared to districts just below the threshold. Similarly, electoral violence decreased by a third standard deviation in treated municipalities. Identifying novel causal mechanisms, we argue that the reduction in levels of criminal conflict are driven by a reform that invigorated political accountability and eroded subnational political hegemonies. In this way, electronic voting strengthened programmatic parties and weakened those more likely to establish pacts with organized criminal groups. This article thus suggests that alternative ways to iron-fist policies can considerably curb crime and contributes to the literature on democratic reforms, elections and violence, and the political economy organized criminal groups.
\end{abstract}

Keywords: democratic reforms, electronic vote, violence and fraud, Brazil

*PhD Candidate. Department of Political Science, University of Notre Dame. E-mail: cnietoma@nd.edu ${ }^{\dagger}$ PhD Student. Department of Political Science, University of Notre Dame. E-mail: nskigin@nd.edu 


\section{Introduction}

While democracy offers the promise of a more peaceful society (Przeworski, 2004, 12), outbreaks of criminal and political violence are not entirely alien to the existence of electoral politics and democratic institutions. In fact, countries in Latin America (Arias, 2006), Sub-Saharan Africa (Fjelde and Höglund, 2016), and South East Asia (Staniland, 2017) are riddled with cases where democratic procedures and political participation are marred with the systematic intimidation and assassination of voters and politicians.

Indeed, much of the conventional wisdom in political science poses a fundamental contradiction between violence and democracy. While democracy is said to be able to channel conflict through peaceful means, the empirical literature shows how, under certain conditions, democratic institutions may trigger violence against its key players and subvert its fundamental principles of contestation and inclusiveness. Political changes in Latin America that were expected to deepen democracy, such as political and fiscal decentralization in Colombia or subnational party alternation in Mexico, have led instead to an upsurge of violence against citizens and state officials (Trejo and Ley, 2018; Chacon, 2013; Taylor, 2009).

In this paper, we challenge this pessimistic finding by studying the unintended consequences of democratizing reforms for the reduction of violence. We theorize and provide empirical evidence suggesting that relatively inexpensive institutional reforms that enfranchise new voters and end rampant fraud can significantly curb levels of conflict and violence, even in contexts of weak institutions and widespread criminal groups. We empirically study this by focusing on the adoption of electronic voting technology in Brazil and study how its implementation in 1998 significantly reduced homicide rates and electoral violence. More than a decade after the transit to democracy, Brazilian authorities sequentially introduced the EV technology as a way to reduce electoral fraud and simplify 
the cumbersome voting process for the country's 5,570 municipalities.

To provide credible estimates of the causal impact of electronic voting on the reduction of violence, we exploit a natural experiment following previous work on Brazil (Fujiwara, 2015; Hidalgo, 2014; Zucco and Nicolau, 2016). Because the reform was part of a modernization process carried out by the federal electoral justice to universally increase political legitimacy and deter election rigging, mayors and other local party activists bore no responsibility for its design and implementation. In fact, due to the country's enormous size and multilevel federal structure, only districts with an electorate over 40,500, as measured two years before the 1998 legislative elections, shifted from traditional paper ballots-associated with widespread fraud in Brazil—to electronic voting. Taking advantage of this arbitrary and exogenous population threshold, we employ a regression discontinuity design (RDD) to compare conflict levels in municipalities barely over and barely below the threshold.

We show that the adoption of EV systematically reduced violence in Brazilian municipalities. The results indicate that homicide rates substantively diminished in municipalities where the electorate size was narrowly above 40,500 , the magnitude that dictated whether electronic vote was adopted, as compared to districts just below the threshold. Substantively, we find that the as-if-random assignment of municipalities to treatment decreased levels of violence by almost one standard deviation. Moreover, our results suggest that the effects of EV on the reduction of violence are persistent and robust several years after its implementation.

Likewise, we show that the institutional reform significantly curbed electoral violence in those districts that shifted from traditional paper ballots to electronic machines. Using original data collected by Albarracín (2018b), our findings indicate that municipalities barely above the threshold experienced fewer assassinations and attacks against their politicians-current of former officeholders, public employees, candidates for public of- 
fice, and local party leaders-during the electoral cycle. Consistent with our argument, we do not find the same result before the EV was introduced or after 1998, when all municipalities used the same voting procedure. Another placebo test indicates that there are no significant effects in non-election years either.

Drawing on evidence from Brazil, we argue that inexpensive institutional reforms, such as electronic voting, can contain levels of violence by altering the incentives of both criminal groups and political actors. We identify two main reasons why electronic voting helped reduce lethal violence. First, because the reform boosted electoral competitiveness, it substantively reduced the power of subnational political hegemonic machines that tend to collude with organized criminal groups. Higher barriers to rampant fraud and an increase in effective enfranchisement (of principally low income, less educated citizens) empowered more ideological and programmatic parties at the expense of personalist, candidate-centered organizations prone to establish close ties with criminals. Second, by significantly reducing local political hegemony and increasing rotation in office, the reform inadvertently improved electoral accountability. In doing so, it encouraged newly elected public authorities to stabilize criminal markets and break political-criminal pacts, which tend to mostly harm neighborhoods where low-income individuals live.

Our paper makes several contributions to the growing body of literature on democracy and violence in the developing world. First, we shed light on the conditions under which violent actors may be deterred from voter intimidation to manipulate electoral results. Recent literature has recognized the interaction between armed groups' power and government policies in determining groups' strategies of electoral involvement (Matanock and Staniland, 2018), and our study pinpoints how exogenous shocks alter the ties between politicians and organized criminal groups (OCGs). Second, while most research on electoral violence has focused on government leaders and state security forces, we stress the role of non-state armed actors with varying degrees of connections 
to incumbents and oppositions (Staniland, 2015).

Third, we seek to better understand the unintended consequences of democratic reforms in weakly institutionalized contexts. While the most popular response to rising levels of violence in Latin America has been the adoption of iron-fist policies, we suggest that democratic-deepening reforms may provide an effective alternative to mano dura strategies that frequently undermined citizen security, human rights, and the legal order (Calderón et al., 2015; Flores-Macías and Zarkin, 2020; Phillips, 2015). Lastly, our contribution stems from our choice of research design. Endogeneity typically makes the violence-reduction effects of democratizing reforms difficult to observe. Because democratization often takes place after an initial liberalization process that granted some rights and acquiesced the masses, and because democracy is not randomly assigned, selection problems pose significant methodological challenges to empirically assess claims from traditional theories of democracy. By taking advantage of a natural experiment, we are able to isolate the effect of a concrete democratic reform on lethal violence, a relationship that has typically eluded scholarly work.

\section{The unintended consequences of electronic voting}

While electoral democracy in contexts of weak institutions and widespread violence is likely to be captured and subverted by de facto political actors, the introduction of concrete democratizing reforms may have positive consequences for the reduction of criminal violence. Our main argument is that relatively inexpensive institutional reforms, such as electronic voting, are capable of effectvely containing the levels of lethal violence by altering the incentives of both political actors and criminal actors. By fostering a large de facto enfranchisement of low income and less educated voters, the introduction of electronic voting led to greater political accountability and the erosion of political hegemonies. This, in 
turn, helped reduce criminal and electoral violence in Brazilian municipalities.

Elections provide citizens with the possibility of holding their authorities accountable and demanding better security and public goods (Kitschelt and Wilkinson, 2007; Smulovitz, 2010). In addition, elections should guarantee regular political turnover and minimize the possibility of entrenched hegemonies. Yet in contexts of insecurity and violence, accountability and political turnover are riddled with obstacles and uncertainty. For one, politicians may have little incentives to respond to the electorate and establish closer relationships with criminal actors (Carey, Colaresi and Mitchell, 2015). In the process, not only is accontability eroded, but it also hampers political turnover. Moreover, violence has a 'demobilizing effect' in the electoral arena, as it tends to push voters away from electoral politics and towards other forms of participation (Bateson, 2012; Carreras and Trelles, 2012).

Electronic voting, we posit, helped reduce criminal violence by strengthening the process of political accountability and eroding political hegemonies. First, electronic voting contributed to the reduction of homicide rates by increasing citizen accountability for greater security. If politicians want to be positively evaluated by voters, they must seek to respond to their demands and satisfy their specific needs. To be sure, while accountability faces a plethora of problems in weakly institutionalized contexts (Stokes, 2005; Tsai, 2007), voters can still hold elected authorities accountable for different issues, including the prevalence of crime and insecurity (Ley, 2017; Holmes and Gutiérrez de Piñeres, 2013). The introduction of EV produced a significant enfranchisement of mostly low income and less educated citizens, whose exposure to violence and insecurity was more prominent. As new swathes of population became electorally important, they resorted to the electoral process to demand higher levels of security and order from elected officials.

Second, electronic voting reduced criminal violence by eroding the hegemony of parties most likely to establish pacts with criminal groups. The enfranchisement of an im- 
portant part of the population favored programmatic political parties as opposed to personalistic parties. The type of party in power is not trivial for criminal politics: as abundant evidence shows, weak and personalistic parties are more likely to establish agreements with criminal groups than strong and programmatic parties. In Brazil, weak and personalistic political parties have more frequently built close ties with criminal groups than stronger party organizations, such as the PT (Albarracín, 2018b). Likewise, both traditional parties in Colombia-Liberal and Conservative-engaged in alliances with paramilitary groups, the prominent actor in most of the alliances were third and weakly organized parties with a personalistic platform (Acemoglu, Robinson and Santos, 2013). Crucially, as the newly enfranchised citizens voted for more programmatic parties, electronic voting inadvertently contributed to the demise of parties that were more likely to favor criminal structures.

\subsection{Expectations}

As we detail below, the introduction of electronic voting technology reduced the occurrence of electoral fraud and produced a large de facto enfranchisement of mostly low income voters. Inadvertently, however, electronic voting contributed to the systematic reduction of homicide rates in Brazilian municipalities by increasing political accountability and eroding the power of political parties most likely to establish relationships with criminal groups. First, we expect electronic voting to have a negative effect on homicide rates in municipalities where this technology was implemented. We also expect electronic voting to have a significantly negative effect on assassinations and murder attempts of political figures in electoral years in municipalities where electronic voting was adopted. In nonelectoral years, political assassinations should not be affected by EV. Lastly, because of the staggered implementation of electronic voting, we also expect the effect to persist but 
decrease in intensity over time, especially after the technology was implemented across all municipalities.

\section{Brazil: democratizing reforms and unexpected effects}

In this paper, we study how and whether the implementation of the electronic voting technology in Brazil had any impact on subsequent levels of violence. By exploiting a population-based discontinuity in the assignment of electronic devices, we explore how relatively cheap democratizing reforms in contexts of relatively weak institutions and pervasive criminal groups may help reduce the levels of lethal violence. Below we briefly describe the implementation of electronic voting in Brazil and the landscape of criminal violence and politicians in Brazilian electoral politics.

\subsection{How electronic voting enfranchised citizens in Brazil}

Shortly after its transit to democracy in 1985, Brazil's party system was characterized by its high electoral volatility, party indiscipline, and weak linkages between voters and politicians (Mainwaring and Scully, 1995; Mainwaring, Power and Bizzarro, 2018). With over 30 parties across 5,570 municipalities, fraud became a commonly used tactic, especially in dominant conservative ruling parties. Not only was casting a ballot a complicated matter for many voters-given the amount of candidates and parties to choose from-but also the counting and reporting process were constantly vulnerable to corruption by political machines. One important democratizing reform introduced in 1998 was the implementation of electronic voting technology. A relevant feature of this change was that its implementation took place first in municipalities above an arbitrary population threshold. Due to a limited supply of devices, only municipalities with more than 40,500 
registered voters, as per the 1996 population, used the technology, while the remaining municipalities used paper ballots (Fujiwara, 2015). Concretely, the 40,500-voter cut point was set by distributing the fixed number of machines available during the electoral period from largest to smallest municipality and determining where it would finish. Because delivering the fixed number of devices to fewer but larger districts is cheaper than allocating machines to a greater number of smaller municipalities, an economy-of-scale criterion was used.

Electronic voting produced a substantive change in how citizens participated in the democratic game. Until 1998, the voting process was prone to errors and not intuitive for all swathes of population. Paper ballots did not list all possible candidates or participating political parties, but required voters to write down the name or number of their preferred options (Hidalgo, 2014). Given the large number of candidates running and different positions, blank and null votes were especially prevalent among illiterate voters (Hidalgo et al., 2010; Zucco and Nicolau, 2016). Under the new technology, casting a ballot became an easier for process, as the new machines provided voters with visual aids and feedback on every step of the process (Fujiwara, 2015).

The impact of this technology was not negligible: according to some conservative estimates, it increased effective franchise in legislative elections by 10\% (Fujiwara, 2015), whereas others calculate de facto enfranchisement augmented by $20 \%$ (de Moraes, 2012) or even 33\% (Hidalgo, 2014). This represented between eight and over 25 millions "new" voters indicating their political intentions in polling stations. This was due to a substantive reduction in residual ballots after facilitation of the voting process, in particular for the poorest and least educated individuals who had difficulty in expressing their choices with paper ballots. Juxtaposition of large district magnitudes with a candidate-centered party system that encouraged organizations to field a large numbers of aspirants made it hard for voters to simply rely on party cues as nominees from the same party also com- 
peted among themselves. Since informationally-demanding contexts complicates voters' ability to suffrage (Brady et al., 2001; Kimball and Kropf, 2008), it is highly unlikely that the unusually large number of blank and null votes ought to be considered a signal of protest against the political system.

Moreover, enfranchised voters were more likely to favor programmatic parties as opposed to personalistic parties. Newly enfranchised voters were much more likely to cast "party list" ballots instead of candidate ones, favoring programmatic and ideologically coherent parties. Altogether, the reform strengthened the country's main parties and debilitated dominant local conservative machines, catch-all and minor parties (Hidalgo, 2014), which are more likely to collude with criminal groups (Albarracín, 2018b).

\subsection{How electronic voting reduced fraud}

The implementation of electronic voting also constituted a progress in leveling the playing field by substantially decreasing the occurrence of electoral fraud. Before the electronic voting was in place, the counting and reporting of ballots was a cumbersome process that opened the possibilities to manipulation. As a decentralized process, it was vulnerable to the penetration of political machines, which resorted to electoral manipulation to maintain their incumbency status across the country. Some improvements did occur after 1985: in 1986 voters were re-registered and a federal list of voters was designed (Nicolau, 2015). Despite these advances, citizen preferences' manipulation was still widespread. For instance, Rio de Janeiro had to repeat its elections for federal and state deputies in 1994 as evidence indicated that election rigging occurred in various places of the state (Tribunal Regional Eleitoral, 2006, 43).

To curb fraudulent tactics at the time of voting, tallying or counting votes, the Superior Electoral Court established electronic machines, which were first used for national- 
and state-level elections in 1998. ${ }^{1}$ Electronic voting machines protected elections from fraudulent tactics. The evidence to support this, though indirect, is quite revealing: while in regions with competitive party systems EV had a negligible effect on the vote share for the incumbent coalition, in regions with hegemonic ruling parties, electronic voting had a negative effect on the support for incumbent candidates (Hidalgo, 2014). The reform removed most of the fraud employed by conservative dominant machines to hold onto power.

In sum, Brazil significantly reduced the potential for fraud at several stages by switching from a decentralized process prone to manipulation by subnational machines to a centralized insulated electoral bureaucracy that, by all accounts, got rid off fraud during the vote count. Hidalgo $(2014,16)$ notes that "no serious cases of fraud in the tabulation process have emerged since the system was first implemented", helping the system achieve legitimacy. A 2008 survey suggested that over $90 \%$ of voters trusted the new system, and both state and federal legislators interviewed in 2008 and 2009 invariably coincided EV had ended fraud during vote tallying.

Diminished election rigging, in turn, increased party systems' competitiveness in subnational units governed by political machines: the vote shares of candidates affiliated to the governor's ruling coalitions substantively diminished in these states.

To be sure, while the adoption of EV can be considered a "democratizing" reform that enfranchised millions of voters and enacted safeguards against election rigging, electronic machines do not always improve the voting process. In other countries, EV has had several problems and faced backlash. Germany, the Netherlands, Norway, Ireland, the United Kingdom and Finland experimented with the new technology but stepped back. Similarly, the Philippines abandoned the system in 2010 after serious suspected

\footnotetext{
${ }^{1}$ State capitals and cities with more than 200,000 voters had experimented with EV for local elections in 1996
} 
fraud in 2010. In the US, Georgia's EV system is allegedly rife with potential exposure to hacking, tampering and malfunctions (Niesse, 2019). Our claim, however, is not that EV is a universal solution to the voting process, but rather that it de facto enfranchised a large percent of the Brazilian lower-income electorate and considerably diminished fraud. And even where it is not clear that EV improves the quality of the electoral process, voters usually associate EV with a faster, more precise, less prone to corruption and fraud, and more confident system (Pomares, Levin and Alvarez, 2014).

We thus study the effect of a democratizing reform without focusing on regimelevel changes as most cross-national studies do. Rather, we inspect lower-order level reforms that were also common in historical experiences of early democratization in which regime changes were not abruptly brought but occurred after a set of institutions were progressively introduced (Capoccia and Ziblatt, 2010). From a theoretical point of view, this is consistent with studies that examined historical democratization processes that mainly increased franchise or remarkably limited fraud, such as the Argentine 1912 reform (Collier, 1999; Przeworski, 2009). From an empirical standpoint, examining smaller changes allows for more credible research designs and estimation of causal effects, deeper understanding of institutional particularities and context, and better measurement of the key variables.

\subsection{Election violence in Brazil: criminal actors and politicians}

Brazil provides an ideal setting to study how democratizing reforms affect election-related violence in unintended ways: despite the transit to democracy in the eighties-followed by other democratizing reforms such as electronic voting-violence took hold of local politics in several regions across the country. As Hoelscher (2015) finds, violence during the military regime was uniform across all states, but after democratization, homicide 
rates took divergent trajectories across these states. By the start of the 21st Century, Brazil had one of the highest homicide rates in South America only followed by Colombia and Venezuela. While some of the literature on Brazil emphasizes the role of inequality, youth bulges, and the rise of drug trade (Ceccato, Haining and Kahn, 2007; Murray, Cerqueira and Kahn, 2013; Cerqueira and Lobâo, 2003) increasing evidence overwhelmingly points to the coexistence of electoral politics and criminal actors as an additional key driver of violence.

There exists wide spatial variation in homicide rates in Brazil. An abundant literature has documented the magnitude of the problem, both in the countryside (Alston, Libecap and Mueller, 1999; Hidalgo et al., 2010) and urban settings (Arias, 2006), with a special focus on favelas, informal urban settlements of squatters where state penetration has been precarious. Many of these areas are controlled and disputed by criminal factions involved with drug-trafficking operations. Urban areas with low state presence became attractive spaces for groups such as Comando Vermelho (CV) and Primeiro Comando da Capital (PCC) that sought establish control over the territory and the retail drug trade in cities such as Rio and São Paulo. The CV's origins can be traced back to the military dictatorship in the 1970s, when left-wing militants and common criminals in prison allied for self-protection and drug trade in subsequent years. Similarly, inspired by the CV's experience, the PCC was born in Sao Paulo's prison system in the 1990's and grew to be Brazil's largest criminal organization with presence in all 27 states (Lessing and Willis, 2019; Insight Crime, 2018). As a reaction to the presence of these groups, Brazil has also witnessed, since at least the 1908s, the emergence and expansion of militia groups, most of which involved the participation of local residents, business leaders, and police officers (Hidalgo and Lessing, 2015).

Criminal involvement in politics is not a rare occurrence in Brazil. Extensive qualitative and quantitative information has suggested that relationships between criminal 
groups and politicians in Brazil are widespread and take multiple forms (Bailey and Taylor, 2009; Albarracín, 2018a). Moreover, clientelistic networks play an important role in sustaining criminal presence in electoral politics: it is through preexisting networks of social leaders and civic organizations that criminal groups are able to have access to local populations and state resources (Arias, 2006). While much of their presence and control can be attained in non-violent ways, violence does constitute an important component of their repertoire. Criminals may use violence against voters and state officials to restrict political competition and ultimately shape policy-making in the areas they seek to control. Violence against politicians can be used as a means to promote friendly candidates, prevent potential challengers to run for office, and against voters to shape their political preferences at the booths. Politicians, of course, are not simple victims of criminals' objectives, but agents of their relationships, especially in cases where parties are weak and political labels are unimportant (Albarracín, 2018a). In some cases, outbreaks of violence may emerge when relationships between politicians and local gangs weaken and when the state decides to increase political repression against them (Lessing, 2017).

Acknowledging the wide variation of criminal groups, political actors, and their relationships, this paper studies how a concrete type of exogenous institutional changeelectronic voting-shapes the incentives of both politicians and criminals to use violence against voters and their political contenders. While the introduction of electronic voting technology sought to increase transparency in the electoral process, it radically changed the conditions for electoral fraud and simplified the voting process for previously disenfranchised voters. In doing so, we contend, it altered the incentives and ability to influence the electoral outcome. Given the involvement of criminal actors in the electoral game and the arbitrary criterion to implement the technology across space, Brazil provides an ideal setting to test the causal story outlined in our theory section. In the following paragraphs, we present our data, research design, and the main findings from two regression 
discontinuity designs.

\section{Testing the Theory: Data and Empirical Strategy}

\subsection{Data}

In the next sections, we estimate the temporal and spatial effects of transparency-enhancing reforms on violence. The main outcome of interest is operationalized as the number of homicides per 100,000 inhabitants in a given municipality. To measure our main dependent variable, we retrieved information from DATASUS, the Ministry of Health's mortality information system. ${ }^{2}$ Despite official statistics might result suspicious in cases of state officials-criminals collusion, DATASUS is regarded as a highly reliable source and has been widely used by the academic community. We use the municipality as our spatial unit of analysis because, in the 1998 legislative elections, electronic machines were introduced in higher-populated municipalities. We assess the annual evolution of violence across Brazilian municipalities.

Even though homicide rates a perfect indicator of criminal violence, several recent studies have relied on this widely-available statistic to measure the level of criminal conflict where finer-grained data are not available (e.g., Trejo, Albarracín and Tiscornia, 2018; Dube, Dube and García Ponce, 2013; Dube and Naidu, 2015; Magaloni, Vivanco and Melo, 2018; Sobrino, 2019). Implicitly or explicitly, these studies follow the United Nations in defining countries with "epidemic" levels of violence when their homicide rates are above 10 per 100,000 inhabitants (UNDP, 2013). According to this definition, thus, most murders in countries such as Brazil, Mexico, and El Salvador can be attributed to OCGs, whereas in Argentina, Chile, and Uruguay most killings are committed by ordi-

\footnotetext{
${ }^{2}$ http://tabnet.datasus.gov.br/cgi/deftohtm.exe?sim/cnv/obt10br.def, accessed October 24th, 2019.
} 
nary criminals. In the period we study, Brazil's homicide rate was always above 25 per 100,000 population (Waiselfisz, 2013), suggesting that our measure captures a large portion of organized criminal violence.

We complement homicide rates with data on electoral violence (Albarracín, 2018b). These data, generated from national and regional newspaper articles, aggregate assassination and assassination attempts against politicians. The data set comprehends murders and attacks against current and former officeholders (city councilors, mayors, state and federal deputies, and governors), public employees (municipal and state secretaries), political candidates and local party activists. Consequently, our second outcome is a count variable that measures the intensity of criminal electoral violence for each municipalityyear.

Contrary to other previous literature that solely focus on attacks against mayors (e.g., Ríos, 2012), Albarracin's data allow us to extend the analysis to a broader range of state authorities and public employees. As noted by Trejo and Ley (2019) in their work on high-profile criminal violence in Mexico, this is relevant as criminal organizations frequently target candidates, party leaders, and subnational bureaucratic structures. These data also permit us to avoid the bias incurred by studies that exclusively concentrate on successful assassinations, which significantly underestimate the degree of violence OCGs can employ.

We analyze the effect of EV adoption in the whole territory but in four states where the new technology was introduced in every municipality regardless of their electorate size: Alagoas, Amapa, Rio de Janeiro, and Roraima. Municipalities in these four states represent only $4 \%$ of the total number of municipalities. While all municipalities in Alagoas and Rio adopted electronic voting because electoral rigging was especially critical, the logic in Amapa and Roraima rested on the attempt to check electoral authority's capacity to distribute the machines in remote and isolated areas. Because our final sample 
does not include some municipalities were both fraud and violence were particularly severe, we believe our estimates might be somewhat conservative. In other words, had Rio de Janeiro and Alagoas been included, the effects we detect would have plausibly been larger.

Electoral data come from the federal electoral authority (Tribunal Superior EleitoralTSE), which published the list of municipalities that effectively used electronic voting. The reports indicate almost perfect compliance. ${ }^{3}$ Further information on municipal characteristics comes from the 1991 Brazilian Census and the agricultural census of 1995 by the Brazilian Institute of Geography and Statistics (IBGE).

Additional covariates employed in this study for robustness and balance tests come from data collected mostly by Hidalgo et al. (2010). These include the following variables: agricultural income, the number of banks in a municipality, a human development index, the proportion of individuals living under extreme poverty, mean income and land inequality, the proportion of the landless population, GDP per capita (logged), the security and social budgets (logged), the annual rain deviation (as weather conditions have been often related to levels of conflict), and the unemployment rate.

\subsection{Empirical Strategy: Regression Discontinuity Design}

The electoral size, directly correlated with municipalities' number of inhabitants, is plausibly correlated with a broad number of geographic and socio-economic features. Consequently, a naive comparison between municipalities with and without EV may confound the effect of other municipal-level characteristics.

To address this problem and estimate effects that are plausibly causal, we use a regression discontinuity design (RDD). RDD compares the outcome barely above and just

\footnotetext{
${ }^{3}$ Only seven out of 5,281 (0.001\%) below the cutpoint had their formal petitions to use electronic machines approved by the TSE. Because noncompliance was so negligible, it does not alter the results.
} 
below a certain threshold that determines assignment to treatment. Given that this cutoff is arbitrary, treatment and control units are expected to be similar in every covariate. In other words, insofar as the other municipal features vary continuously with the "forcing" or running variable, any difference in the outcome is attributable to the treatment. If it is true that treatment were as-if-random, then every other covariate should be balanced. Below, though, we provide evidence that differences between treated and controlled municipalities in economic and social variables—such as GDP per capita, rural and overall population, land inequality, and education—are close to zero and statistically insignificant.

Mirroring previous studies that analyzed the effects of electronic voting (Hidalgo, 2014; Fujiwara, 2015; Zucco and Nicolau, 2016), the electorate size is our forcing variable that determines whether electronic machines or traditional paper ballots were used. In particular, electronic voting was adopted only in districts with over 40,500 population, as measured two years before the 1998 legislative elections. Formally, a municipality $m$ received treatment $T$ if

$$
T_{m}=\left\{\begin{array}{l}
1 \text { if electorate }(\mathrm{t}-2) \geq 40,500 \\
0 \text { if electorate }(\mathrm{t}-2)<40,500
\end{array}\right.
$$

Following conventional practice in the literature, we estimate local polynomial regressions with triangular kernel functions. Concretely, while our main results stem from estimations with local linear polynomials $(p=1)$, we also report results with quadratic polynomials $(p=2)$ for robustness purposes. Because higher-order polynomials $(p>2)$ may lead to the over-fitting of the data, we restrict our analyses to linear and quadratic estimations. Lastly, we use one common MSE-optimal bandwidth selector.

More specifically, because the bandwidth researchers adopt entails a trade-off be- 
tween efficiency and bias, we follow Calonico, Cattaneo and Titiunik (2014) and employ the optimal bandwidth, the bias corrected estimator, and robust standard errors. These represent an improvement upon non-parametric local polynomial estimators commonly used to create confidence intervals for treatment effects. We check the robustness of the results only for linear and quadratic polynomials as higher-order polynomials have been shown to return misleading confidence intervals, noisy weighted averages of the outcomes for the treated and control units, and sensitivity to the degree of the polynomial (Gelman and Imbens, 2019).

\subsection{Testing model assumptions}

Credibly estimating the effect of electronic voting technology on homicide rates faces a number of challenges. For one, the new technology was not assigned in a random fashion, but based on the size of the electorate. As a result, a naive approach that regresses homicide rates on the presence of electronic voting is likely to confound the effect of this technology with a number of observed and unobserved covariates. This approach would certainly yield biased estimates. In addition, sharper critics could even suggest that the relationship between homicides and electronic voting is opposite to the one we defend in this paper: it could very well be that the prevalence of violence and fraud, which tends to be amplified in larger municipalities, prompted politicians to consider the implementation of the technology.

Our regression discontinuity design minimizes these issues and considers that whether or not an observation receives the treatment is as-if random. The validity of this design, however, largely depends on a series of key assumptions. First, our research design is based on the assumption that municipalities within a reasonable window are identical on all observed and unobserved characteristics. Because the only difference 
between municipalities within such window is that fact that some adopted electronic voting, any discontinuous change in violence should be attributed to the introduction of EV and not to any other factor. For instance, we would want to rule out the possibility that the distribution of electronic machines in 1998 is not correlated with a municipality's pretreatment levels of wealth, inequality, education, development, or access to markets.

Figure 1: Covariate Balance
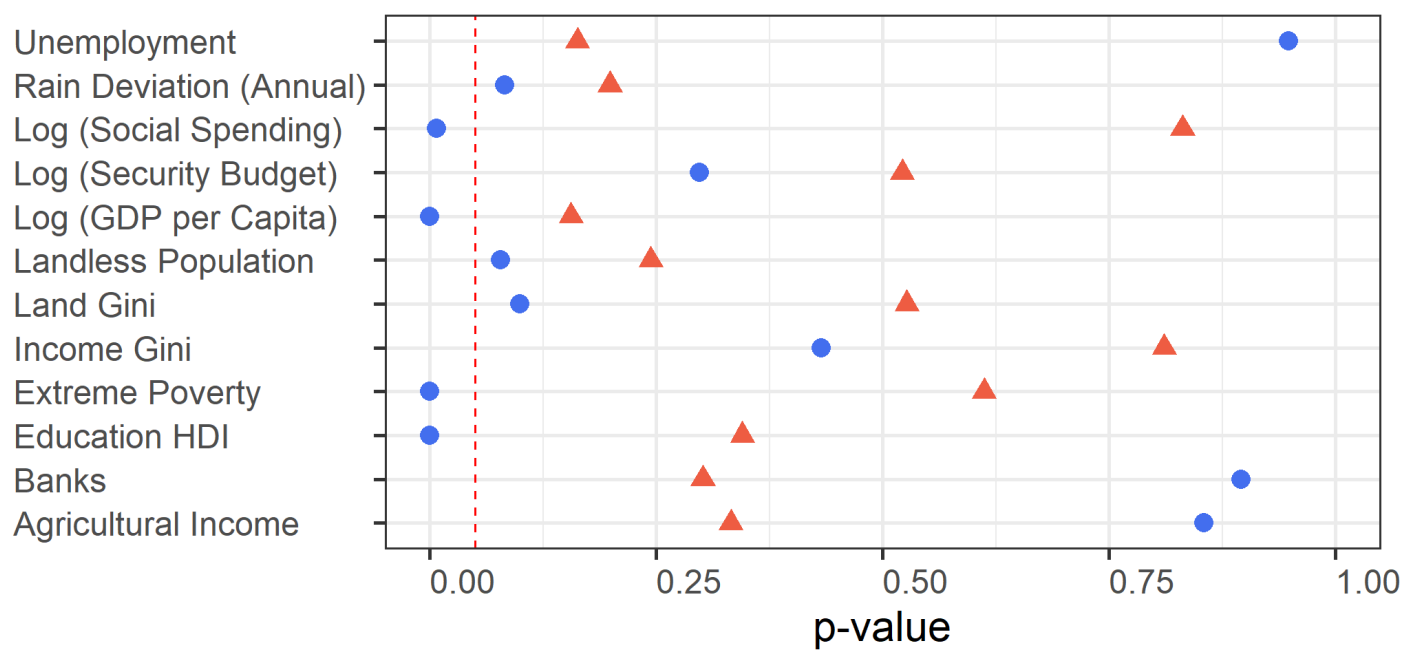

Specification - Full $\Delta$ Local

Note: The figure shows balance tests for a number of relevant pre-treatment covariates across Brazilian municipalities using two model specifications. Circles represent OLS estimates using the entire sample; triangles represent RD estimates based on local polynomial regressions with robust biased-corrected confidence intervals.

We test the plausibility of this assumption by reporting estimates of $\beta_{1}$ for municipal features measured prior to the establishment of EV. Concretely, Figure 1 shows balance statistics for a dozen relevant covariates using two different apporaches: a local linear specification that uses observations within an optimal bandwidth and an OLS 
specification that uses the entire sample. When using a local linear approach—our main specification-we find no statistically significant differences at the cutpoint between treatment and control municipalities. Moreover, the fact that there are some covariates reaching statistical significance at the 5\% level when using the full sample reinforces the need to focus our analysis on the RDD, which achieves excellent overall covariate balance. In sum, the RDD improves balance for most covariates and none of them is statistically significant (i.e., $p>.05)$.

A second, key assumption is that the density function of the forcing variableelectorate size-is continuous. In other words, we should not expect to observe a jump in electorate size around the cutoff of 40,500 , as this would invalidate our identification strategy. If mayors and other local authorities were able to manipulate the electorate size so as to sort their towns and change their treatment status, then changes in levels of violence may be attributable not to EV adoption but to other factors, likely connected to the ability of municipalities to be placed at either side of the cut point. We contend that this is highly implausible: not only would changing the electorate size raise serious flags to federal authorities, but the specific way in which EV was implemented made it practically impossible to manipulate the electorate size. Concretely, while the notion that EV would be gradually implemented was known from 1995, the resolution on which municipalities would employ it in the 1998 elections was only anticipated a few months before the election.

We formally provide evidence of no sorting behavior, suggesting that local authorities were not able to systematically manipulate the electorate size. Following McCrary (2008), we test the null hypothesis of no discontinuous jump of the forcing variable around the cutoff. A discontinuous jump in either direction would suggest that municipalities with EV are systematically more likely to have either more or less violence, thus invalidating our results. With a p-value of .47 , we fail to reject the null hypothesis of no 
Figure 2: McCrary test: Sorting around the electorate threshold

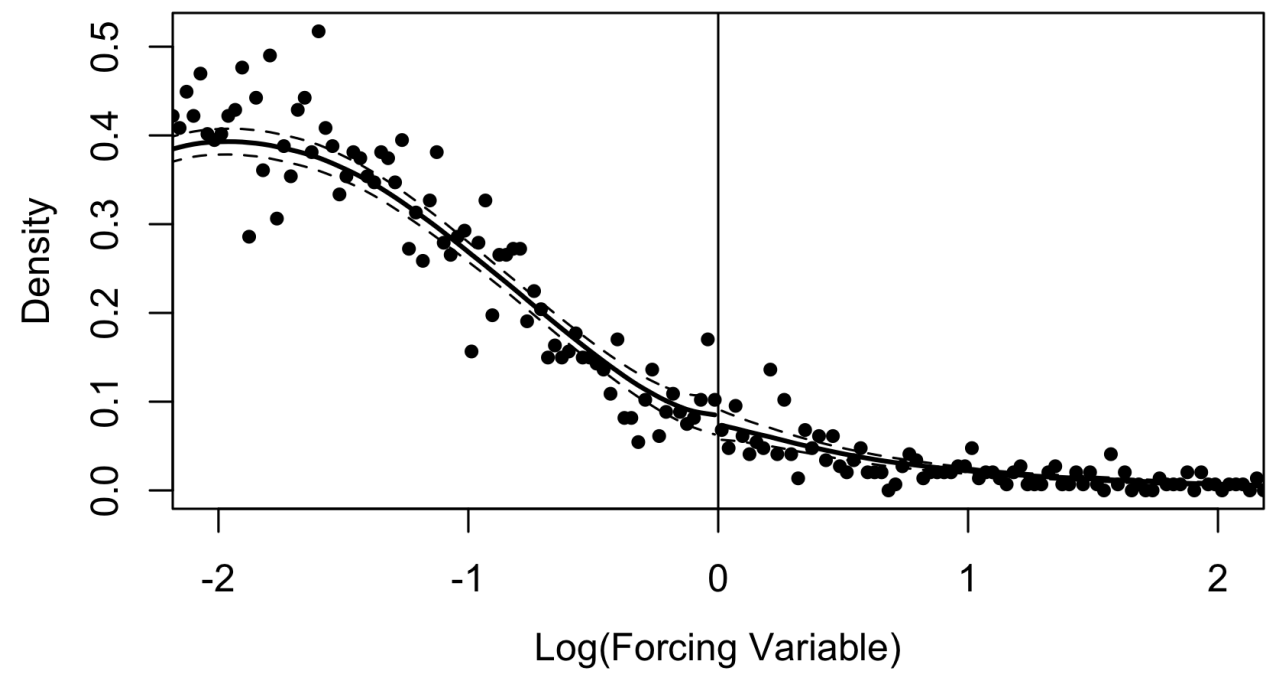

Note: The forcing variable is the electorate size normalized to set the cut point to zero. Discontinuity estimate (standard error): -0.11 (.17). P-value: .47.

sorting, which augments the credibility of our design. Figure 2 displays the result of this test, showing no jump in the density at the cut point.

\section{Empirical Findings}

\subsection{Baseline results}

Table 1 reports our main results implementing Calonico, Cattaneo and Titiunik (2014) non-parametric estimates for the period 1998-2002. Our main findings indicate that as-ifrandom adoption of electronic voting machines leads to a substantive and statistically significant reduction in violence in Brazilian municipalities. Panel A presents the results stemming from first-degree local polynomials, whereas Panel B displays results of quadratic polynomials. Because covariates should not have an important impact on our 
results, Table 1 does not include any controls. However, because incorporating them may improve the precision of our estimates, we incorporate them in the Appendix and show that our results are robust to their inclusion.

Our results indicate that, whether we employ a linear or a quadratic polynomial, electronic voting diminishes conflict during term in office. Our results are significant in all specifications, although they are generally substantively larger in the quadratic specification. This is not surprising, as higher-order polynomials risk overfitting.

Table 1: RD effects of electronic voting on homicide rates

\begin{tabular}{|c|c|c|c|c|c|c|}
\hline & \multicolumn{6}{|c|}{$\begin{array}{l}\text { Panel A: Linear polynomial } \\
\text { Homicide rates by period: }\end{array}$} \\
\hline & 1998 & 1999 & 2000 & 2001 & 2002 & 1998-2002 \\
\hline Electronic voting & $\begin{array}{c}-6.63^{* *} \\
(3.00)\end{array}$ & $\begin{array}{c}-6.86^{* *} \\
(3.15)\end{array}$ & $\begin{array}{c}-8.05^{* *} \\
(3.29)\end{array}$ & $\begin{array}{c}-6.79^{* *} \\
(3.31)\end{array}$ & $\begin{array}{c}-5.63^{*} \\
(3.25)\end{array}$ & $\begin{array}{c}-6.83^{* *} \\
(2.92)\end{array}$ \\
\hline Total observations & 5084 & 5084 & 5084 & 5084 & 5084 & 5084 \\
\hline Effective observations & 584 & 452 & 553 & 562 & 620 & 531 \\
\hline \multirow[t]{3}{*}{ Bandwidth } & 0.67 & 0.53 & 0.63 & 0.64 & 0.71 & 0.60 \\
\hline & \multicolumn{6}{|c|}{$\begin{array}{c}\text { Panel B: Quadratic polynomial } \\
\text { Homicide rates by period: }\end{array}$} \\
\hline & 1998 & 1999 & 2000 & 2001 & 2002 & 1998-2002 \\
\hline Electronic voting & $\begin{array}{l}-11.37^{* * *} \\
(3.48) \\
\end{array}$ & $\begin{array}{c}-9.76^{* * *} \\
(3.62) \\
\end{array}$ & $\begin{array}{c}-8.46^{* *} \\
(3.63)\end{array}$ & $\begin{array}{c}-8.37^{* *} \\
(3.78)\end{array}$ & $\begin{array}{c}-5.94^{*} \\
(3.36)\end{array}$ & $\begin{array}{c}-8.83^{* * *} \\
(3.27) \\
\end{array}$ \\
\hline Total observations & 5084 & 5084 & 5084 & 5084 & 5084 & 5084 \\
\hline Effective observations & 651 & 670 & 930 & 846 & 1409 & 797 \\
\hline Bandwidth & 0.67 & 0.53 & 0.63 & 0.64 & 0.71 & 0.83 \\
\hline
\end{tabular}

Note: All models are based on local polynomial regressions with robust biasedcorrected confidence intervals, triangular kernel functions and use one common MSE optimal bandwidth selection procedure (Calonico, Cattaneo and Titiunik, 2014).

Panel A suggests that the introduction of EV resulted in a reduction of 5.63 to 8.05 in the homicide rates per 100,000 inhabitants. This represents a substantively relevant decrease, as it is equivalent to 1.2 to 1.7 times the 1997 sample mean and $36 \%-52 \%$ of its standard deviation. Importantly, we find null effects when we use as a dependent 
variable the homicide rates in 1997, a year prior to the change in the technology used to cast ballots. Panel B, in turn, reports even more substantial results. Models that employ quadratic polynomials indicate that assignment of electronic machines significantly curbed crime. Specifically, EV diminished violence by 5.94 (as of 2002) to 11.37 (in 1998) murders per 100,000 population.

Figure 3 visually illustrates our results. The graph normalizes the (logged) electoral size in 1996 to set the cut point to zero and plots the effect of EV on homicide rates employing a second-degree local polynomials. The plot shows an evident negative jump in levels of violent crime across the cutoff.

Figure 3: Effect of Electronic Voting on Homicide Rates

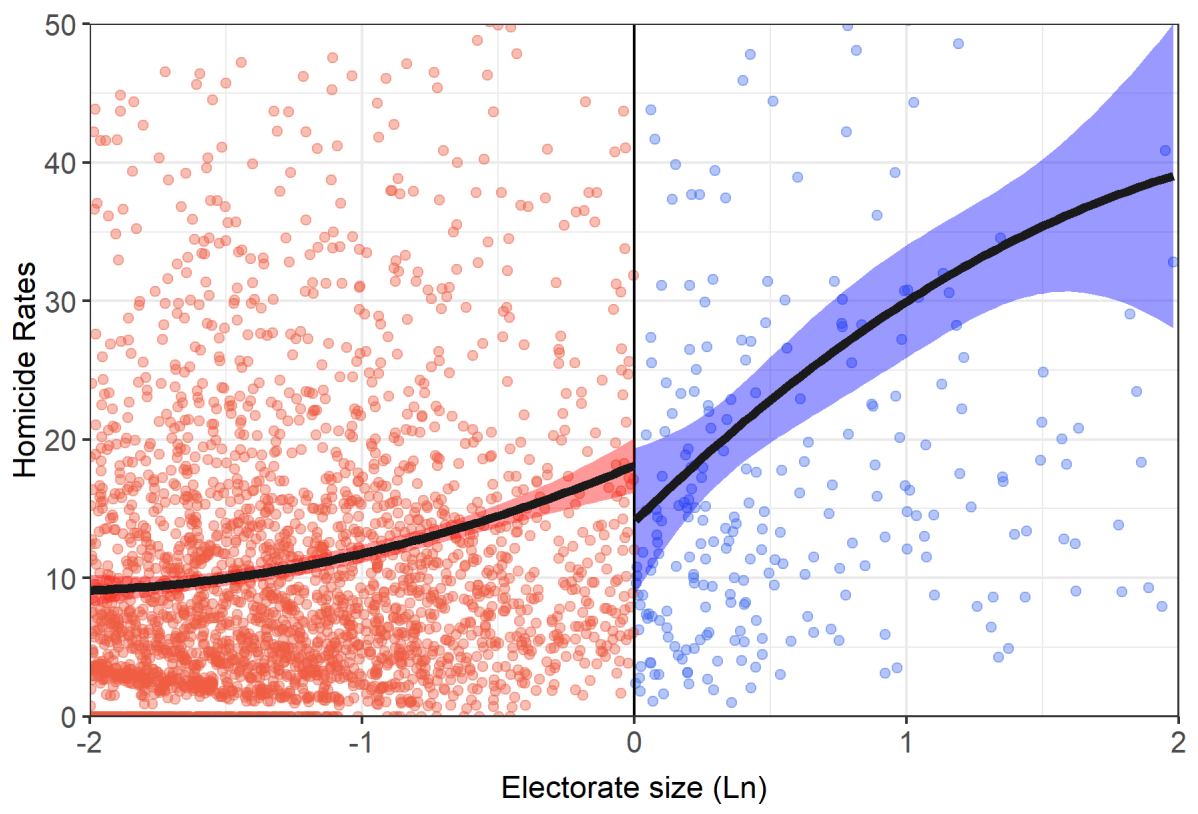

Note: The forcing variable is the electorate size (logged) normalized to set the cut point to zero. The graph plots a quadratic polynomial. 


\subsection{Placebo and falsification tests}

While our research design allows us to credibly estimate the effect of electronic voting on lethal violence, we provide a series of additional tests that gives us the confidence that it was the introduction of electronic voting in 1998, and not other factors, what produced a reduction in homicide rates. Concretely, we conduct a series of falsification tests using different cutoffs, pre-treatment outcomes, and a measure of political assassinations.

Figure 4: Placebo test: pre-treatment homicide rates

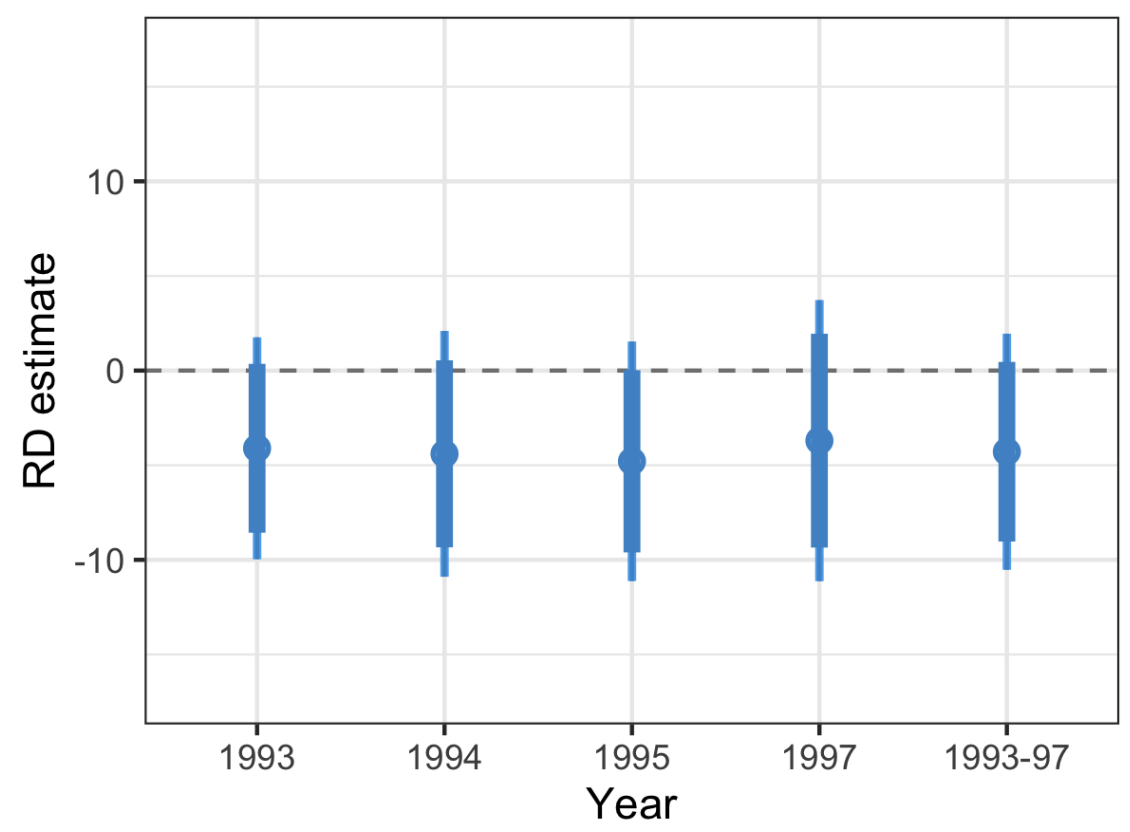

Note: The graph plots robust bias-corrected RD estimates with 95 and 99 confidence intervals. As it is the case with the main results, all models are based on local polynomial regressions with robust biased-corrected confidence intervals, triangular kernel functions and use one common MSE optimal bandwidth selection procedure.

First, we use pre-treatment homicide rates as a placebo test. Because municipallevel homicide rates changed as a result of EV, we should not expect to see statistically significant changes prior to its introduction in 1998. We plot separate RD estimates for 
the the 1993-1997 period (and its average) with 95 and 99\% confidence intervals. As suggested by Figure 4, electronic voting does not have a statistically significant effect on homicide rates prior to 1998 at conventional levels. Moreover, the results are particularly insignificant in 1997, one year before the treatment year.

Figure 5: Effect at different cutoffs (placebo test)

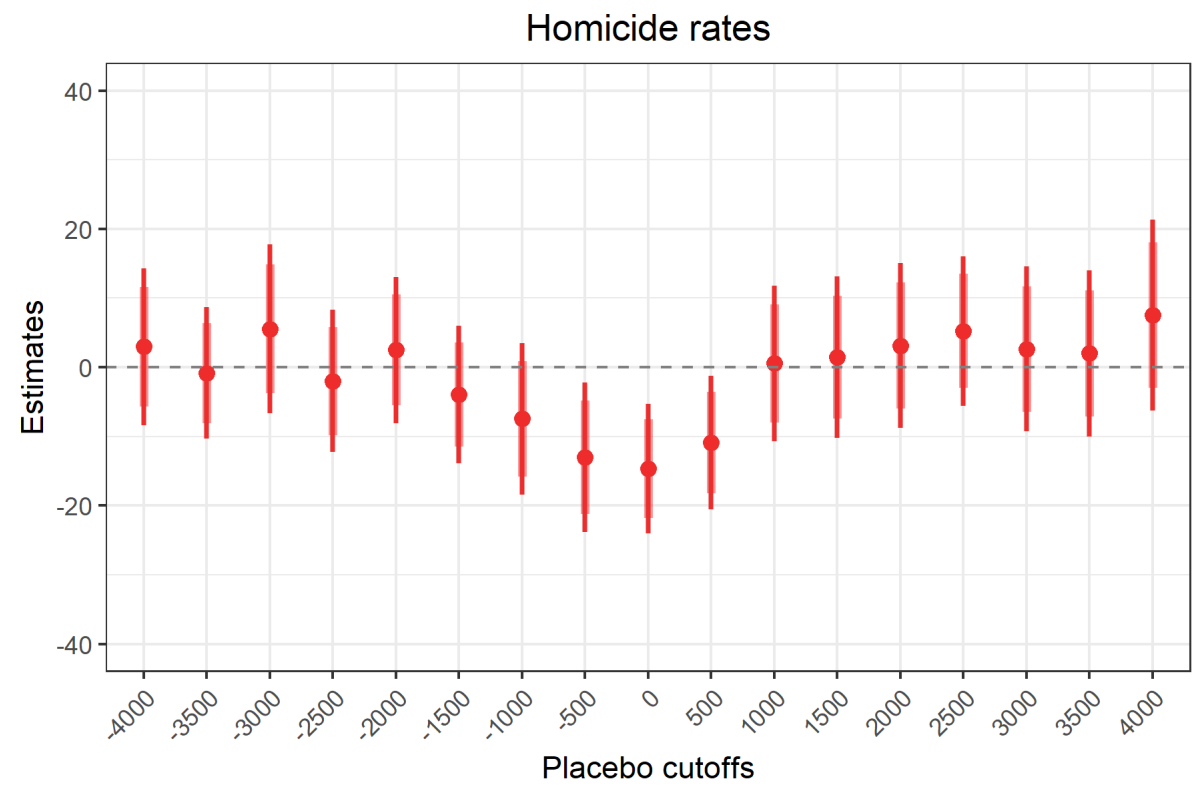

Note: The forcing variable is the electorate size (logged) normalized to set the cut point to zero. As it is the case with the main results, all models are based on local polynomial regressions with robust biased-corrected confidence intervals, triangular kernel functions and use one common MSE optimal bandwidth selection procedure.

Second, we examine whether the the treatment effect yields statistical significance when using other cutoffs across the range of the forcing variable. We plot the results in Figure 5. It is around the 40,500 cutoff where we should observe an effect of EV on violence. A propensity to observe significant discontinuities in correspondence of placebo cutoffs would cast doubts on the smoothness assumption behind our RD design. Thus if our empirical design is valid, we should not expect electronic voting to have negative 
and statistically significant effects in cutoffs different from the one that actually assigned towns to treatment and control groups. The placebo test shows that the treatment effect is only significant close to the cut point, but it vanishes and becomes statistically insignificant once we move away from the threshold. Consequently, the tendency to find significant jumps away from the actual cutoff is very low. Consistent with the baseline results, therefore, violent crime diminishes close to the true cut point, but there is no registered discontinuity in other thresholds.

Lastly, we conduct a falsification test using political assassinations and murder attempts as an outcome variable. Our theory predicts that electoral violence should have also diminished in treated municipalities in 1998, when EV was adopted in districts whose electorate size was over 40,500 (as of 1996). Because this type of violence occurs in election time, we should not observe a significant drop in the number political assassinations and attacks in non-electoral years. Moreover, we should not expect any significant change in such violent events during electoral years in which all municipalities employed the same voting procedure (as occurred in 2000).

Table 2: RD effects of electronic voting on electoral criminal violence

\begin{tabular}{lcccc}
\hline \hline & \multicolumn{4}{c}{ Assassinations and murder attempts: } \\
\cline { 2 - 5 } & 1998 & 1999 & 2000 & 2001 \\
\hline Electronic voting & $-0.015^{* *}$ & -0.002 & 0.004 & 0.001 \\
& $(3.00)$ & $(3.15)$ & $(3.29)$ & $(3.31)$ \\
\hline Total observations & 5237 & 5237 & 5237 & 5237 \\
Effective observations & 3160 & 395 & 265 & 362 \\
Bandwidth & 2.07 & 0.47 & 0.30 & 0.43 \\
\hline${ }^{* * *} p<0.01,{ }^{* *} p<0.05,{ }^{*} p<0.1$. & & &
\end{tabular}

Note: All models are based on local polynomial regressions with robust biased-corrected confidence intervals, triangular kernel functions and use one common MSE optimal bandwidth selection procedure (Calonico, Cattaneo and Titiunik, 2014). 
Table 2 reports the results of the effect of EV on murders and assassination attempts. We find that electoral violence substantively diminished in 1998, when only some municipalities employed electronic machines and others still used traditional paper ballots. The magnitude of the effect is substantial: it represents roughly a third of the variable's standard deviation and almost ten times its mean for 1998. Furthermore, and consistent with our argument, we fail to find significant results for non-election years (such as 1999 and 2001) and the following election year in which all municipalities used EV (2000).

\section{Discussion}

This paper has shown that an institutional reform intended to curb widespread levels of fraud also significantly reduced levels of violence. Enhanced accountability and increased rotation in office likely dismantled criminal networks formed by hegemonic local elites with connections to the national politics. Consequently, effective enfranchisement and higher turnover resulted in lower criminal conflict. These results run contrary to recent literature that show that subnational alternation in office increases violence (Trejo and Ley, 2018) and challenge the notion that electoral violence and bribery are substitutes (Collier and Mahoney, 2012). While some anecdotal evidence suggests that incumbent coalitions unable to use fraud resorted to voter intimidation, our findings suggests that both homicide rates and violence against politicians dramatically dropped after EV adoption. ${ }^{4}$

Brazil's recent history displays a dramatic spike in the use of violence in a context where politicians and non-state armed actors have built strategic relationships. These connections also imply that substantial parts of the country's territory are controlled not

\footnotetext{
4See, e.g., "Terror Electrônico", Agencia Globo, September 28, 1998.
} 
by the state but by fações criminosas and milícias-though frequently in association with the state (Lessing, 2017; Arias, 2006; Albarracín, 2018a). Although the country has at times intended to curb violence through pacifying police units, as in Rio de Janeiro ahead of the 2014 World Cup and the 2016 Olympic Games, authorities' dominant response throughout the country was based on a mano dura logic. As in other parts of Latin America and elsewhere, iron first policies have often backfired. In Mexico, for instance, President Felipe Calderón's War on Drugs largely increased criminal violence, contrary to their proponents' goals (Phillips, 2015; Calderón et al., 2015). Given the notorious failure of heavyhanded policies, democratizing reforms may offer a promising alternative.

Our findings are thus relevant for other crime-ridden countries as well. Experiences from violent places suggest that subtler reforms can better address violent conflict. In Colombia, for instance, Medellín reduced violence partly by developing a public transportation system that connected isolated low-income neighborhoods to the city's urban center (Cerdá et al., 2012). In line with our findings, other experiences also suggest the importance of dismantling criminal networks to diminish conflict levels. Cruz (2011) focuses on the need to implement security sector reforms to control violence produced by criminals in conjunction with state institutions and actors. Trejo and Nieto-Matiz (2019) show how cooperation between international organizations and local judicial institutions dismantled pacts between Guatemalan state security forces and OCGs that created criminal structures to ensure control of illicit markets. Finally, Trejo, Albarracín and Tiscornia (2018) claim that transitional justice mechanisms upon democratization helped countries limit the dramatic levels of violence suffered where such extraordinary mechanisms did not exist. Similarly, our findings suggest that removing hegemonic politicians from office can severely break up collusion with OCGs and shrink violent crime.

Lastly, our article provides compelling evidence that some transparency-enhancing reforms can indeed reduce violence, a long-term established theoretical connection that 
has been either poorly investigated or faced with a mixed empirical record. While democratization is supposed to be accompanied by peace because competitive elections provide channels through which to solve political disputes, few studies were able to find such relationship in new democracies. We do find that a democratic reform diminished criminal conflict and, more related to this hypothesis, electoral violence. Rife with bribery and voter intimidation, the introduction of EV limited the possibility of committing fraud and decreased the number of political assassinations and murder attempts. 


\section{References}

Acemoglu, Daron, James A Robinson and Rafael J Santos. 2013. "The Monopoly of Violence: Evidence from Colombia." Journal of the European Economic Association 11(S1):544.

Albarracín, Juan. 2018a. "Criminalized Electoral Politics in Brazilian Urban Peripheries." Crime, Law and Social Change 69(4):553-575.

Albarracín, Juan. 2018b. Criminalized Electoral Politics. The Socio-Political Foundations of Electoral Coercion in Democratic Brazil PhD thesis University of Notre Dame.

Alston, Lee, Gary Libecap and Bernardo Mueller. 1999. Titles, Conflict, and Land Use: The Development of Property Rights and Land Reform on the Brazilian Amazon Frontier. Ann Arbor: University of Michigan Press.

Arias, Enrique Desmond. 2006. "The Dynamics of Criminal Governance: Networks and Social Order in Rio de Janeiro." Journal of Latin American Studies 38(02):293-325.

URL: http://journals.cambridge.org/article_S0022216X06000721

Bailey, John and Matthew M Taylor. 2009. "Evade, Corrupt, or Confront? Organized Crime and the State in Brazil and Mexico." Journal of Politics in Latin America 1(2):3-29. URL: http://journals.sub.uni-hamburg.de/giga/jpla/article/view/38

Bateson, Regina. 2012. "Crime Victimization and Political Participation." American Political Science Review 106(03):570-587.

URL: http://journals.cambridge.org/article_S0003055412000299

Brady, Henry, Justin Buchler, Matt Jarvis and John McNulty. 2001. Counting All the Votes: The Performance of Voting Technology in the United States. Technical report Survey Research Center and Institute of Governmental Studies, UC Berkeley.

Calderón, Gabriela, Gustavo Robles, Alberto Díaz-Cayeros and Beatriz Magaloni. 2015. "The Beheading of Criminal Organizations and the Dynamics of Violence in Mexico." Journal of Conflict Resolution 59(8):1455-1485.

Calonico, Sebastian, Matias Cattaneo and Rocío Titiunik. 2014. "Robust Nonparametric Confidence Intervals for Regression-Discontinuity Designs." Econometrica 82(6):22952326.

Capoccia, Giovanni and Daniel Ziblatt. 2010. "The Historical Turn in Democratization Studies: A New Research Agenda for Europe and Beyond." Comparative Political Studies 43(8/9):931-968.

Carey, Sabine C, Michael P Colaresi and Neil J Mitchell. 2015. "Governments, Informal Links to Militias, and Accountability." Journal of Conflict Resolution p. 0022002715576747. URL: http://jcr.sagepub.com/content/early/2015/04/06/0022002715576747 
Carreras, Miguel and Alejandro Trelles. 2012. "Bullets and Votes: Violence and Electoral Participation in Mexico." Journal of Politics in Latin America 4(2):89-123.

Ceccato, Vânia, Robert Haining and Tulio Kahn. 2007. "The geography of homicide in São Paulo, Brazil." Environment and Planning A 39(7):1632-1653.

Cerdá, Magdalena, Jeffrey D. Morenoff, Ben B. Hansen, Kimberly J. Tessari Hicks, Luis F. Duque, Alexandra Restrepo and Ana V. Diez-Roux. 2012. "Reducing Violence by Transforming Neighborhoods: A Natural Experiment in Medellín, Colombia." American Journal of Epidemiology 175(10):1045-1053.

Cerqueira, Daniel and Waldir Lobâo. 2003. Condiçôes socioeconômicas, polícia e produçâo criminal. Rio de Janeiro, Brazil: Diretoria de Estudos Macroeconomicos, IPEA, Instituto de Pesquisa Econoomica Aplicada.

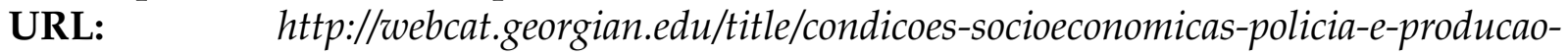
criminal/oclc/948219648

Chacon, Mario L. 2013. "In the Line of Fire: Political Violence and Decentralization in Colombia.".

URL: $h$ ttp://papers.ssrn.com/abstract $=2386667$

Collier, David and James Mahoney. 2012. "Insights and Pitfalls: Selection Bias in Qualitative Research." World Politics 49(1):56-91.

Collier, Ruth Berins. 1999. Paths Toward Democracy: The Working Class and Elites in Western Europe and South America. Cambridge: Cambridge University Press.

Cruz, José Miguel. 2011. "Criminal Violence and Democratization in Central America: The Survival of the Violent State." Latin American Politics and Society 53(4):1-33.

de Moraes, Murilo Ferreira. 2012. Voting Technology and Political Competition: Lessons From Overlapping Political Races in Brazil Master's thesis University of São Paulo.

Dube, Arindrajit, Oeindrila Dube and Omar García Ponce. 2013. “Cross-Border Spillover: U.S. Gun Laws and Violence in Mexico." American Political Science Review 107(3):397417.

Dube, Oeindrila and Suresh Naidu. 2015. “Bases, Bullets, and Ballots: The Effect of US Military Aid on Political Conflict in Colombia." The Journal of Politics 77(1):249-267.

Fjelde, Hanne and Kristine Höglund. 2016. "Electoral Institutions and Electoral Violence in Sub-Saharan Africa." British Journal of Political Science 46(2):297-320.

URL: $\quad$ https://www.cambridge.org/core/journals/british-journal-of-politicalscience/article/electoral-institutions-and-electoral-violence-in-sub-saharan-

africa/3EAE320E957EEFFCC2D23C0253C8CAD0 
Flores-Macías, Gustavo and Jessica Zarkin. 2020. "The Militarization of Law Enforcement: Evidence from Latin America." Perspectives on Politics .

Fujiwara, Thomas. 2015. "Voting Technology, Political Responsiveness, and Infant Health: Evidence From Brazil." Econometrica 83(2):423-464.

Gelman, Andrew and Guido Imbens. 2019. "Why High-Order Polynomials Should Not Be Used in Regression Discontinuity Designs." Journal of Business and Economic Statistics 37(3):447-456.

Hidalgo, Daniel. 2014. Digital Democratization: Expanding the Electorate through Voting Technology. Technical report MIT.

URL: Unpublished Manuscript.

Hidalgo, F. Daniel and Benjamin Lessing. 2015. “Endogenous State Weakness: Paramilitaries and Electoral Politics.".

Hidalgo, F. Daniel, Suresh Naidu, Simeon Nichter and Neal Richardson. 2010. "Economic Determinants of Land Invasions." Review of Economics and Statistics 92(3):505-523.

Hoelscher, Kristian. 2015. "Politics and social violence in developing democracies: Theory and evidence from Brazil." Political Geography .

Holmes, Jennifer S. and Sheila Amin Gutiérrez de Piñeres. 2013. "Security and economic voting: Support for incumbent parties in Colombian presidential elections." Democratization 20(6):1117-1143.

Insight Crime. 2018. "First Capital Command: PCC.".

URL: https://www.insightcrime.org/brazil-organized-crime-news/first-capital-command-pccprofilel

Kimball, David and Martha Kropf. 2008. "Voting technology, ballot measures, and residual votes." American Politics Research 36(4):479-509.

Kitschelt, Herbert and Steven I Wilkinson. 2007. Patrons, Clients and Policies: Patterns of Democratic Accountability and Political Competition. Cambridge University Press.

URL: https://books.google.com/books?id=oKs6oahafjoC

Lessing, Benjamin. 2017. Making Peace in Drug Wars: Crackdowns and Cartels in Latin America. Cambridge: Cambridge University Press.

Lessing, Benjamin and Graham Denyer Willis. 2019. "Legitimacy in criminal governance: Managing a drug empire from behind bars." American Political Science Review 113(2):584-606.

Ley, Sandra. 2017. "Electoral Accountability in the Midst of Criminal Violence: Evidence from Mexico." Latin American Politics and Society 59(1):3-27. 
Magaloni, Beatriz, Edgar Franco Vivanco and Vanessa Melo. 2018. "Killing in the Slums: The Problems of Social Order and Police Violence in Rio De Janeiro.".

URL: https://papers.ssrn.com/sol3/papers.cfm?abstract_id=3010013

Mainwaring, Scott, Timothy J. Power and Fernando Bizzarro. 2018. The uneven institutionalization of a party system: Brazil. In Party Systems in Latin America: Institutionalization, Decay, and Collapse.

Mainwaring, Scott and Timothy R Scully. 1995. Building Democratic Institution: Party Systems in Latin America. Stanford, CA: Stanford University Press.

Matanock, Aila and Paul Staniland. 2018. "How and Why Armed Groups Participate in Elections." Perspectives on Politics 16(3):710-727.

McCrary, Justin. 2008. "Manipulation of the Running Variable in the Regression Discontinuity Design: A Density Test." Journal of Econometrics 142(2):698-714.

Murray, Joseph, Daniel Ricardo de Castro Cerqueira and Tulio Kahn. 2013. "Crime and violence in Brazil: Systematic review of time trends, prevalence rates and risk factors.".

Nicolau, Jairo. 2015. "Impact of Electronic Voting Machines on Blank Votes and Null Votes in Brazilian Elections in 1998." Brazilian Political Science Review 9(3):3-20.

Niesse, Mark. 2019. "Mystery of missing votes deepens as Congress investigates Georgia.".

URL: https://www.ajc.com/news/state-regional-govt-politics/mystery-missing-votes-deepenscongress-investigates-georgia/x4OTYOylxfA0Z0Rg6wjkyN/

Phillips, Brian. 2015. "How Does Leadership Decapitation Affect Violence? The Case of Drug Trafficking Organizations in Mexico." Journal of Politics 77(2):324-336.

Pomares, Julia, Ines Levin and R. Michael Alvarez. 2014. “Do Voters and Poll Workers Differ in Their Attitudes Towards E-Voting? Evidence from the First E-Election in Salta, Argentina." Journal of Election Technology and Systems 2(2):1-10.

Przeworski, Adam. 2004. Democracy and Economic Development. In The Evolution of Political Knowledge: Democracy, Autonomy, and Conflict in Comparative and International Politics, ed. Edward Mansfield and Richard Sisson. Columbus: The Ohio State University Press pp. 300-324.

Przeworski, Adam. 2009. "Conquered or Granted? A History of Suffrage Extensions." British Journal of Political Science 39(02):291-321.

Ríos, Viridiana. 2012. El asesinato de periodistas y alcaldes en México y su relación con el crimen organizado. In Las bases sociales del crimen organizado y la violencia en México, ed. José Aguila. Mexico City: CIES-SSP pp. 275-307. 
Smulovitz, Catalina. 2010. Judicialization in Argentina: Legal Culture or Opportunities and Support Structures? In Cultures of Legality: Judicialization and Political Activism in Latin America, ed. Javier Couso, Rachel Sieder and Alexandra Huneeus. New York: Cambridge University Press pp. 234-253.

Sobrino, Fernanda. 2019. "Mexican Cartel Wars: Fighting for the U.S. Opioid Market.". URL: https://www.fersobrino.com/files/DraftPaper.pdf

Staniland, Paul. 2015. "Armed Groups and Militarized Elections." International Studies Quarterly 59(4):694-705.

Staniland, Paul. 2017. "Armed Politics and the Study of Intrastate Conflict." Journal of Peace Research 54(4):459-467.

Stokes, Susan. 2005. "Perverse accountability: A formal model of machine politics with evidence from Argentina." American Political Science Review 99(3):315-325.

Taylor, Steven L. 2009. Voting Amid Violence: Electoral Democracy in Colombia. Boston: Northeastern University.

URL: https://books.google.com/books?id=xr_7dHPt9pAC

Trejo, Guillermo and Camilo Nieto-Matiz. 2019. "Containing Large-Scale Criminal Violence through Internationalized Prosecution. How the CICIG Contributed to the Reduction of Guatemala's Murder Rate.".

Trejo, Guillermo, Juan Albarracín and Lucía Tiscornia. 2018. “Breaking State Impunity in Post-Authoritarian Regimes: Why Transitional Justice Processes Deter Criminal Violence in New Democracies." Journal of Peace Research 55(6):787-809.

Trejo, Guillermo and Sandra Ley. 2018. "Why Did Drug Cartels Go to War in Mexico? Subnational Party Alternation, the Breakdown of Criminal Protection, and the Onset of Large-Scale Violence." Comparative Political Studies 51(7):900-937.

Trejo, Guillermo and Sandra Ley. 2019. "High-Profile Criminal Violence: Why Drug Cartels Murder Government Officials and Party Candidates in Mexico." British Journal of Political Science pp. 1-27.

Tribunal Regional Eleitoral, Rio Grande do Sul. 2006. Voto eletrônico: edição comemorativa. Technical report.

Tsai, Lily L. 2007. Accountability without Democracy: Solidary Groups and Public Goods Provision in Rural China. Cambridge University Press.

URL: https://books.google.com/books?id=B0oxnuDMI2EC

UNDP. 2013. Citizen Security with a Human Face. New York: United Nations. 
Waiselfisz, Julio Jacobo. 2013. Mapa da Violência 2013. Homicídios e Juventude no Brasil. Technical report CEBELA/Flacso Brasil Rio de Janeiro: .

URL: https://web.archive.org/web/20140211030602/http://www.cebela.org.br/site/common/pdf/Mapa_2013_Jo

Zucco, Cesar and Jairo Nicolau. 2016. "Trading Old Errors for New Errors? The Impact of Electronic Voting Technology on Party Label Votes in Brazil." Electoral Studies 43(September):10-20. 